\title{
Penerapan Decision Tree Data Mining Pada Produksi Kelapa Sawit PT Hindoli Di Sungai Lilin Kabupaten Musi Banyuasin
}

\author{
Atika Kurnia ${ }^{1}$, Ahmad Haidar Mirza ${ }^{2}$, Andri $^{3}$ \\ ${ }^{1,2}$ Informatics Departement, Bina Darma University, Palembang, Indonesia \\ ${ }^{3}$ Information System Departement, Bina Darma University, Palembang, Indonesia \\ Email: ${ }^{1}$ atikakurnia123@gmail.com, ${ }^{2}$ haidarmirza@binadarma.ac.id, ${ }^{3}$ andri@binadarma.ac.id
}

\begin{abstract}
Data mining is an interesting pattern extraction of large amounts of data. PT Hindoli itself has a decision support information system that applies the $\mathrm{c} 4.5$ data mining algorithm. Given the large amount of data available, data mining estimates that palm oil production for a month is from production data. As one of the companies engaged in processing palm oil and producing palm oil, palm oil, and high-quality seed oil, which are grown by farmers into materials that can be sold and will be distributed to production data. The method used is the decision tree method to explore data, find hidden relationships between a number of prospective variables, among others, the number of producing oil palm based on the year, production, competition, and price, resulting in data accumulation or data grouping every month. Input with the target variable is expected to help PT Hindoli in monitoring palm oil processing.
\end{abstract}

Keywords: decision tree, weka, data mining, algoritma C4.5

\section{PENDAHULUAN}

Saat ini dunia teknologi computer berkembang sangat pesat memiliki aktivitas informasi yang cepat dan akurat, hal-hal baru unik menarik dari beragama perkembangan yang terus meningkat dan bermunculan setiap harinya. Pada awalnya computer hanya digunakan untuk menghitung mengolah data, karena kata computer sendiri berasal dari kata "to compute" yaitu alat menghitung. Menurut Suyanto (2017), Data Mining juga Merupakan bidang dari beberapa bidang keilmuan yang menyatukan teknik dari pembelajaran mesin, pengenal, pola, statistik, database, dan visualisasi untuk pengenalan permasalahan pengambilan informasi dari database yang besar. Menurut Suyanto (2017), Data mining juga dilakukan dalam perusahaan untuk mencari normasi dengan perusahaan luar. Hal ini karena banyak perusahaan luar yang berupaya untuk mendapatkan competitive interliligence. 
Teknologi data mining memiliki peranan penting dalam dunia bisnis yang semakin kompetitif. Data mining mampu memanfaatkan aset penting perushaan yaitu data bisnis yang jumlahnya sangat besar sehingga dapat menghasilkan informasi yang belum pernah terpelajari sebelumnya. Prosesnya pun sudah sangat banyak diterapkan dalam bisnis perusahaan proses menganalisis data untuk menemukan pola untuk menghasilkan pengetahuan. Menurut Suyanto (2017), Data mining adalah ektraksi pola yang menarik dari data dalam jumlah besar Suatu pola dikatakan menarik apabila pola tersebut tidak sepele, implisit, tidak diketahui sebelumnya, dan berguna. Pola yang disajikan haruslah mudah dipahami, berlaku untuk data yang akan diprediksi dengan derajat kepastian tertentu, berguna, dan baru. Menurut Suyanto (2017), Beberapa teknik data mining yang umum digunakan diantaranya adalah regresi, decision tree, jaringan saraf tiruan, k-neareast neighbour, naive bayes, dan lain-lain.

PT. Hindoli Di Sungai lilin Kabupaten Musi Baanyuasin merupakan investasi pertama dalam bidang perkebunan kelapa sawit diindonesia yang berkerja sama dengan pihak tranmigrasi sebagai pelaksana pembuat kebun plasma kelapa sawit dan bekerja sama dengan pihak perbank yang bertanggung jawab perawatan kebun sampai belum lunas angkat kredit setelah lunas angkat kredit buah kelapa sawit layak untuk dipanen dan produksi kebun kelapa sawit dengan maksimal yang memproduksi efb,cpo,kernel,acid oil, fibre, shlee, solid, minyak sawit, biji sawit. Dan minyak berkualitas tinggi, yang akan digiling oleh PT. Hindoli diolah menjadi produk setengah jadi dalam bentuk minyak kelapa sawit crude palm oil ( $\mathrm{CPO}$ ) dan inti kelapa sawit.

Berdasarkan hasil dari data produksi tercancum manual dengan file excel ditemukan beberapa permasalahan seperti informasi penggunaan data produksi membutuhkan waktu lama. Demikian untuk keperluan penyediaan atau stok produksi sullit diprediksi. Berkaitan dengan permasalahan yang terjadi ini peneliti terfokus untuk menggunakan metode decision tree untuk klasifikasi suatu fungsionalitas yang akan dihasilkan model yang mampu memprediksi produksi didalam suatu perusahaan seperti halnya yang terdapat pada PT. Hindoli.

\section{METODOLOGI PENELITIAN}

\subsection{Data Selection}

Data produksi digunakan pada penelitian ini berasal dari PT. Hindoli di Di Sungai Lilin Kabupaten Musi Banyuasin, yaitu data produksi dari tahun 20162017, data produksi yang digunakan 143 data pruduksi, yang terdiri dari 9 atribut yaitu tahun, bulan, Tenaga keja, Area (ha), Today, Mtd, Ytd, jenis 
produksi, keterangan. Dari 9 atribut kemudian diseleksi dijadikan 7 atribut yang akan digunakan dalam proses knowledge discovery in database ( $k d d)$, yaitu Tenaga keja, Area (ha), Today, Mtd, Ytd,jenis produksi, keterangan. Untuk keterangan dari atribut-atribut tersebut dapat.

Tabel 1. Atribut produksi

\begin{tabular}{ll}
\hline Atribut Produksi & KeteranganAtribut Produksi Kelapa sawit \\
\hline Tenaga kerja & Merupakan penduduk yang berada dalam usia kerja \\
Area(Ha) & Merupakan luas tempat kerja \\
Today & Merupakan komponen produksi data harian \\
MTD & Merupakan komponen produksi data bulanan \\
YTD & Merupakan komponen produksi data tahunan \\
Jenis Produksi & Merupakan komponen nama-nama produksi \\
Keterangan & Merupakan dalam penghasilkan produksi \\
\hline
\end{tabular}

\subsection{Pre-processing}

Adapun dalam tahap pre-processing ini akan dilakukan langkah-langkah untuk menghasilkan dataset yang bersih sehingga nantinya dapat digunakan dalam tahap berikutnya yaitu tahap mining dengan tujuan memperoleh informasi yang bermanfaat.

\subsection{Knowledge Discovery In Database (KDD)}

KDD berhubungan dengan teknik integrasi dan penemuan ilmiah, interprestasi dan visualisasi dari pola-pola sejumlah kumpulan data. Knowledge Discovery In Database (KDD) adalah keseluruhan proses nontrivial untuk mencari dan mengidentifikasi pola (pattern) dalam data, dimana pola yang ditemukan bersifat sah, baru dapat bermanfaat dan dapat dimengerti.

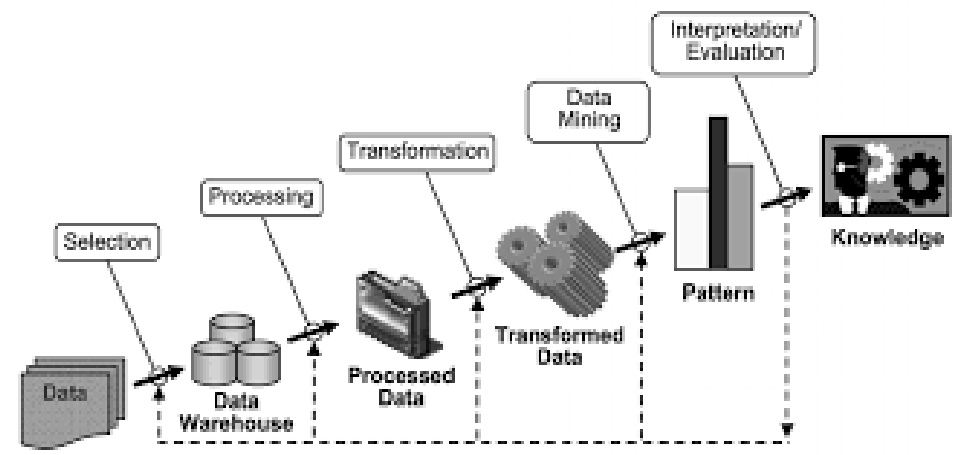

Gambar 3.1 Knowledge Discovery in Database (Han J dan Kember, 2006) 


\section{1) Data Cleaning}

Tahap pembersihan data (cleaning) merupakan tahap awal dari proses KDD. Seluruh atribut pada dataset diatas selanjutnya akan diseleksi sedemikian rupa untuk mendapatkan atribut-atribut yang berisi nilai-nilai yang relevan. Tidak mendapat missing value, dan redundont data dimana syarat tersebut merupakan syarat yang wajib dilakukan dalam proses dan mining sehingga diperoleh sebuah dataset yang berisi untuk digunakan tahap mining data. Dikatakan missing value adalah jika atribut-atribut dalam dataset tidak berisi nilai atau kosong, sementara itu data dikatakan redundont adalah jika dalam satu atau dataset yang terdapat lebih dari satu record data yang berisi nilai ataupun data yang sama dan data sebelum dirubah terdapat record yang terdapat missing value ada 10 record, data yang akan ditampilkan adalah data yang dimana kondisi salah satu dari atribut Tenaga keja, Area (ha), Today, $M t d, Y t d$, jenis produksi, keterangan.

Tabel 2 Data missing Value

\begin{tabular}{lllllll}
\hline $\begin{array}{c}\text { Jenis } \\
\text { produksi }\end{array}$ & Today & \multicolumn{1}{c}{ Mtd } & \multicolumn{1}{c}{ Ytd } & $\begin{array}{c}\text { Tenaga } \\
\text { kerja }\end{array}$ & $\begin{array}{c}\text { Area } \\
\text { Ha }\end{array}$ & Keterangan \\
\hline Efb & 185.97 & 8.545 .49 & 59.819 .07 & 45 & 5.12 & Menurun \\
Cpo & 1745.5 & 8.020 .72 & 51.020 .72 & 56 & 5.53 & Meningkat \\
Kernel & 44.62 .2 & $2, .172 .83$ & 14.649 .54 & 60 & 3.22 & Meningkat \\
Acid oil & 0 & 0 & 0 & 53 & 5.29 & Menurun \\
Fibre & 107.45 & 4.93 .37 & 34.562 .09 & 61 & 1.99 & Menurun \\
shell & 41.33 & 1.439 .42 & 13.293 .12 & 66 & 1.94 & Meningkat \\
solid & 31.33 & 66.220 .45 & 1.439 .42 & 43 & 4.14 & Menurun \\
Efb & 327.15 & 5.880 .70 & 66.220 .45 & 49 & 5.3 & Meningkat \\
Cpo & 307.15 & 5.880 .70 & 57.423 .27 & 56 & 5.13 & Menurun \\
kernel & 85.32 & 1.534 .84 & 16.184 .38 & 62 & 3.54 & menurun \\
\hline
\end{tabular}

Pada tabel 2 ditemukan berapa record yang memiliki nilai 0 sehingga dihapus. Data tersebut harus dibersihkan dengan cara dihapus, dengan menggunakan MS. Excel, data yang kosong dipisahkan dan dijadikan dalam satu file. Penghapusan dilakukan secara manual sebelum data Microsoft Excel jumlah dataset yang awalnya 143 menjadi 124 .

Tabel 3 Data Setelah di Cleaning.

\begin{tabular}{lcccccl}
\hline $\begin{array}{c}\text { Jenis } \\
\text { produksi }\end{array}$ & Today & Mtd & Ytd & $\begin{array}{c}\text { Tenaga } \\
\text { kerja }\end{array}$ & $\begin{array}{c}\text { Area } \\
\text { Ha }\end{array}$ & Keterangan \\
\hline Efb & 185.97 & 8.545 .49 & 59.819 .07 & 45 & 5.12 & Menurun \\
Cpo & 1745.5 & 8.020 .72 & 51.020 .72 & 56 & 5.53 & Meningkat \\
Kernel & 44.62 .2 & $2, .172 .83$ & 14.649 .54 & 60 & 3.22 & Meningkat
\end{tabular}


http://journal.jis-institute.org/index.php/jpsii/index

\begin{tabular}{llllccl}
\hline $\begin{array}{c}\text { Jenis } \\
\text { produksi }\end{array}$ & Today & \multicolumn{1}{c}{ Mtd } & Ytd & $\begin{array}{c}\text { Tenaga } \\
\text { kerja }\end{array}$ & $\begin{array}{c}\text { Area } \\
\text { Ha }\end{array}$ & Keterangan \\
\hline Acid oil & 0 & 0 & 0 & 53 & 5.29 & Menurun \\
Fibre & 107.45 & 4.93 .37 & 34.562 .09 & 61 & 1.99 & Menurun \\
shell & 41.33 & 1.439 .42 & 13.293 .12 & 66 & 1.94 & Meningkat \\
solid & 31.33 & 66.220 .45 & 1.439 .42 & 43 & 4.14 & Menurun \\
Efb & 327.15 & 5.880 .70 & 66.220 .45 & 49 & 5.3 & Meningkat \\
Cpo & 307.15 & 5.880 .70 & 57.423 .27 & 56 & 5.13 & Menurun \\
kernel & 85.32 & 1.534 .84 & 16.184 .38 & 62 & 3.54 & menurun \\
\hline
\end{tabular}

\section{2) Integrasi Data}

Tahap integrasi data adalah tahap penggabungan data dari berbagai sumber, Adapun data produksi terdapat kemudian untuk area $(\mathrm{ha})$ merupkan data peta, adapun sisanya merupakan data produksi. Dri sumber data tersebut dikelompokan menjadi produksi kelapa sawit.

\section{3) Transformasi Data}

Adapun tahap transformasi data adalah pada tahap ini data akan diubah menjadi data yang sesuai untuk proses mining. Dataset dengan format (.xlsx) akan di-export lagi kedalam format "csv" (Comma Delimited) karena software yang digunakan hanya dapat membaca file data dengan format "csv" (Comma Delimited). Berikut dataset yang telah sesuai untuk proses mining di-export ke dalam format "csv" yang siap dilakukan proses data mining.

Tabel 4 Dataset dengan format"xlsx".

\begin{tabular}{lllllll}
\hline $\begin{array}{c}\text { Jenis } \\
\text { produksi }\end{array}$ & Today & \multicolumn{1}{c}{ Mtd } & Ytd & $\begin{array}{c}\text { Tenaga } \\
\text { kerja }\end{array}$ & $\begin{array}{c}\text { Area } \\
\text { Ha }\end{array}$ & Keterangan \\
\hline Efb & 185.97 & 8.545 .49 & 59.819 .07 & 43 & 5.12 & Meningkat \\
Cpo & 1745.5 & 8.020 .72 & 51.020 .72 & 52 & 3.45 & Meningkat \\
Kernel & 44.62 .2 & $2, .172 .83$ & 14.649 .54 & 58 & 1.82 & Meningkat \\
Acid oil & 0 & 0 & 0 & 58 & 4.48 & Menurun \\
Fibre & 107.45 & 4.93 .37 & 34.562 .09 & 63 & 2.28 & Meningkat \\
shell & 41.33 & 1.439 .42 & 13.293 .12 & 42 & 1.85 & Meningkat \\
solid & 31.33 & 66.220 .45 & 1.439 .42 & 51 & 4.92 & Menurun \\
Efb & 327.15 & 5.880 .70 & 66.220 .45 & 62 & 1.52 & Meningkat \\
Cpo & 307.15 & 5.880 .70 & 57.423 .27 & 43 & 3.58 & Menurun \\
kernel & 85.32 & 1.534 .84 & 16.184 .38 & 43 & 2.28 & menurun \\
\hline
\end{tabular}


http://journal.jis-institute.org/index.php/jpsii/index

Tabel 5. Dataset dengan format "csv".

\begin{tabular}{lllllcl}
\hline $\begin{array}{c}\text { Jenis } \\
\text { produksi }\end{array}$ & Today & \multicolumn{1}{c}{ Mtd } & \multicolumn{1}{c}{ Ytd } & $\begin{array}{c}\text { Tenaga } \\
\text { kerja }\end{array}$ & $\begin{array}{c}\text { Area } \\
\text { Ha }\end{array}$ & Keterangan \\
\hline Efb & 185.97 & 8.545 .49 & 59.819 .07 & 43 & 5.12 & Meningkat \\
Cpo & 1745.5 & 8.020 .72 & 51.020 .72 & 52 & 3.45 & Meningkat \\
Kernel & 44.62 .2 & $2, .172 .83$ & 14.649 .54 & 58 & 1.82 & Meningkat \\
Acid oil & 0 & 0 & 0 & 58 & 4.48 & Menurun \\
Fibre & 107.45 & 4.93 .37 & 34.562 .09 & 63 & 2.28 & Meningkat \\
shell & 41.33 & 1.439 .42 & 13.293 .12 & 42 & 1.85 & Meningkat \\
solid & 31.33 & 66.220 .45 & 1.439 .42 & 51 & 4.92 & Menurun \\
Efb & 327.15 & 5.880 .70 & 66.220 .45 & 62 & 1.52 & Meningkat \\
Cpo & 307.15 & 5.880 .70 & 57.423 .27 & 43 & 3.58 & Menurun \\
kernel & 85.32 & 1.534 .84 & 16.184 .38 & 43 & 2.28 & menurun \\
\hline
\end{tabular}

Karena perangkat lunak yang digunakan untuk data mining adalah Weka sebelum diimport data disimpan (save) dalam format csv. Dataset diatas telah memiliki format yang sesuai untuk tahap data mining menggunakan teknik classify, data produksi telah dilakukan proses transformasi maka data diatas siap untuk melanjutkan ke proses selanjutnya.

\subsection{Contoh Penyelesaian Menggunakan Decision Tree}

Kasus yang diselesaikan menggunakan Decision Tree adalah data produksi kelapa untuk menentukan meningkat atau menurun produksi kelapa sawit.

kita akan menguji 5 record sebagai data sampel Untuk menentukan meningkat atau menurunnya produksi berdasarkan data training. Ada tujuh atribut yang digunakan, yaitu :

Tenaga kerja - numeric jumlah min jumlah max

Area-numeric - jumlah min jumlah max

Today-numeric- jumlah min jumlah $\max$

Mtd-numeric- jumlah min jumlah max

Ytd- numeric- jumlah min jumlah max

Jenis produksi-numeric- jumlah $\min$

Keterangan- numeric -jumlah min jumlah max

Tabel 6. Data sample

\begin{tabular}{lllllcl}
\hline $\begin{array}{c}\text { Jenis } \\
\text { produksi }\end{array}$ & Today & \multicolumn{1}{c}{ Mtd } & \multicolumn{1}{c}{ Ytd } & $\begin{array}{c}\text { Tenaga } \\
\text { kerja }\end{array}$ & $\begin{array}{c}\text { Area } \\
\text { Ha }\end{array}$ & Keterangan \\
\hline Efb & 185.97 & 8.545 .49 & 59.819 .07 & 43 & 5.12 & Meningkat \\
Cpo & 1745.5 & 8.020 .72 & 51.020 .72 & 52 & 3.45 & Meningkat \\
Kernel & 44.62 .2 & $2, .172 .83$ & 14.649 .54 & 58 & 1.82 & Meningkat \\
Acid oil & 0 & 0 & 0 & 58 & 4.48 & Menurun
\end{tabular}


http://journal.jis-institute.org/index.php/jpsii/index

\begin{tabular}{lcccccl}
\hline $\begin{array}{c}\text { Jenis } \\
\text { produksi }\end{array}$ & Today & Mtd & Ytd & $\begin{array}{c}\text { Tenaga } \\
\text { kerja }\end{array}$ & $\begin{array}{c}\text { Area } \\
\text { Ha }\end{array}$ & Keterangan \\
\hline Fibre & 107.45 & 4.93 .37 & 34.562 .09 & 63 & 2.28 & Meningkat \\
\hline
\end{tabular}

Secara umum Decision Tree untuk membangun pohon keputusan adalah sebagai berikut:

1. Pilih atribut sebagai akar

2. Buat cabang untuk masing-masing nilai

3. Bagi kasus dalam cabang

4. Ulangi proses untuk masing-masing cabang semua kasus pada cabang memiliki kelas yang sama.

Menghitung jumlah kasus, jumlah kasus untuk keterangan meningkat, jumlah kasus untuk keterangan menurun, dan Entopy dari semua kasus dan kasus yang dibagi berdasarkan atribut area(ha), today, $m t d, y t d$, jenis produksi, keterangan.

\begin{tabular}{|c|c|c|c|c|c|c|c|}
\hline \multirow{2}{*}{ Node } & & & Jml Kasus (S) & Meningkat & Menurun & Entropy & Gain \\
\hline & Total & & 5 & 2 & 3 & & \\
\hline & $\begin{array}{l}\text { Tenaga } \\
\text { Kerja }\end{array}$ & & & & & & \\
\hline & & $<=45$ & 3 & 3 & 2 & & \\
\hline & & $>45$ & 2 & 3 & 1 & & \\
\hline & $\begin{array}{l}\text { area } \\
\text { (ha }\end{array}$ & & & & & & \\
\hline & & $<=5.12$ & 3 & 3 & 2 & & \\
\hline & & $>5.12$ & 3 & 3 & 2 & & \\
\hline & Today & & & & & & \\
\hline & & $<=1$ & 4 & 2 & 3 & & \\
\hline & & $>1$ & 2 & 2 & 3 & & \\
\hline & MTD & & & & & & \\
\hline & & $<=0$ & 3 & 3 & 2 & & \\
\hline & & $>0$ & 3 & 2 & 2 & & \\
\hline & YTD & & & & & & \\
\hline & & $<=1400$ & 2 & 3 & 2 & & \\
\hline & & $>1400$ & 3 & 3 & 2 & & \\
\hline
\end{tabular}

Gambar 1. Perhitungan Node 1

Baris total kolom Entopy pada tabel 3.10 dapat dicari dengan menggunakan rumus berikut ini :

Entropy $($ Total $)=\sum_{i=1}^{n}-p i \log 2 p i$

Gain $($ total tenaga kerja) $=$

Gain $($ total area(ha)) =

$$
\begin{aligned}
& =\text { entropy (total) } \\
& -\quad \sum_{i=1}^{n}\left|\frac{\text { tenaga kerja }}{\text { total }}\right| * \text { entropy }(\text { area }(h a)
\end{aligned}
$$

$$
\text { - } \quad \sum_{i=1}^{n} \mid \frac{\mid \text { today } \mid}{\mid \text { total } \mid} * \text { Entopy (today) }
$$


Gain $($ total mtd $)=$

Gain $($ total ytd $)=$

$$
\text { Entopy (total) }-\sum_{i=1}^{n} \mid \frac{|m t d|}{\mid \text { total } \mid} * \text { Entopy }(m t d)
$$

$$
\text { Entopy (total) }-\sum_{i=1}^{n} \mid \frac{|y t d|}{\mid \text { total } \mid} * \text { Entopy }(y t d)
$$

Kesimpulan :

1. Atribut dengan Gain tertinggi diproduksi

2. Atribut produksi

3. Nilai atribut produksi yaitu 2 bulan keterangan meningkat dan menurun.

\section{HASIL DAN PEMBAHASAN}

\subsection{Data Mining}

Metode decision tree memiliki banyak model dan algoritma untuk setiap kasus salah satunya adalah model klasifikasi dengan Decision Tree Seperti disebutkan sebelumnya pada data mining terdapat beberapa langkah yaitu: pembersihan data yaitu untuk menghilangkan noise dan data yang tidak konsisten, Integrasi data yaitu bebrapa sumber data dapat dikombinasikan, seleksi data yaitu data yang relevan dengan kebutuhan yang diambil dari basis data, transformasi data yaitu data diubah ke dalam bentuk data yang sesuai untuk mining, Data mining yaitu proses esensial dimana metode cerdas diaplikasikan untuk mengekstrak pola data, Evaluasi pola yaitu untuk mengidentifikasi pola yang benar-benar menarik yang mewakili pengetahuan.

\subsubsection{Penerapan klasifikasi dengan Decision Tree}

Kasus yang diselesaikan menggunakan decision tree adalah data produksi kelapa untuk menentukan meningkat atau menurun produksi kelapa sawit. kita akan menguji 5 record sebagai data sampel Untuk menentukan meningkat atau menurunnya produksi berdasarkan data training. Ada tujuh atribut yang digunakan, yaitu :

Tenaga kerja - numeric jumlah min jumlah max

Area-numeric - jumlah min jumlah max

Today-numeric- jumlah min jumlah max

Mtd-numeric- jumlah min jumlah max

Ytd-numeric- jumlah min jumlah max

Jenis produksi-numeric- jumlah min

Keterangan- numeric -jumlah min jumlah max. 
Tabel 7. Data sample

\begin{tabular}{lllllll}
\hline $\begin{array}{l}\text { Jenis } \\
\text { produksi }\end{array}$ & Today & Mtd & Ytd & $\begin{array}{l}\text { Tenaga } \\
\text { kerja }\end{array}$ & $\begin{array}{l}\text { Area } \\
\text { Ha }\end{array}$ & Keterangan \\
\hline Efb & 185.97 & 8.545 .49 & 59.819 .07 & 43 & 5.12 & Meningkat \\
Cpo & 1745.5 & 8.020 .72 & 51.020 .72 & 52 & 3.45 & Meningkat \\
Kernel & 44.62 .2 & $2, .172 .83$ & 14.649 .54 & 58 & 1.82 & Meningkat \\
Acid oil & 0 & 0 & 0 & 58 & 4.48 & Menurun \\
Fibre & 107.45 & 4.93 .37 & 34.562 .09 & 63 & 2.28 & Meningkat \\
\hline
\end{tabular}

Secara umum decision tree untuk membangun pohon keputusan adalah sebagai berikut :

1. Pilih atribut sebagai akar

2. Buat cabang untuk masing-masing nilai

3. Bagi kasus dalam cabang

4. Ulangi proses untuk masing-masing cabang semua kasus pada cabang memiliki kelas yang sama.

Menghitung jumlah kasus, jumlah kasus untuk keterangan meningkat, jumlah kasus untuk keterangan menurun, dan Entopy dari semua kasus dan kasus yang dibagi berdasarkan atribut area(ha), today, $m t d, y t d$, jenis produksi, keterangan. Setelah itu melakukan perhitungan Gain untuk masing-masing atribut. Hasil perhitungan ditunjukkan pada Gambar 2.

\begin{tabular}{|c|c|c|c|c|c|c|c|}
\hline Node & & & $\begin{array}{l}\text { Jml } \\
\text { Kasus } \\
\text { (\$) }\end{array}$ & Meningkat & Menurun & Entropy & Gain \\
\hline & Total & & 5 & 2 & 3 & 0,97095084 & \\
\hline & $\begin{array}{l}\text { Tenaga } \\
\text { Kerja }\end{array}$ & & & & & & \\
\hline & & $<=45$ & 3 & 3 & 2 & & $-26,83684$ \\
\hline & & $>45$ & 2 & 3 & 1 & & \\
\hline & area (ha) & & & & & & \\
\hline & & $\Leftrightarrow=5.12$ & 3 & 3 & 2 & & 2,19297 \\
\hline & & $>5.12$ & 3 & 3 & 2 & & \\
\hline & Today & & & & & & \\
\hline & & $<=1$ & 4 & 2 & 3 & & 0,3529998 \\
\hline & & $>1$ & 2 & 2 & 3 & & \\
\hline & Mtd & & & & & & 0,97095084 \\
\hline & & $<=0$ & 3 & 3 & 2 & & \\
\hline & & $>0$ & 3 & 2 & 2 & & \\
\hline & Ytd & & & & & & \\
\hline & & $<=1400$ & 2 & 3 & 2 & & $-864,16039$ \\
\hline & & $>1400$ & 3 & 3 & 2 & & \\
\hline
\end{tabular}

Gambar 2. Perhitungan Gain 
Berdasarkan hasil yang didapatkan pada Gambar 2, maka sebagai langkah pertama variabel pilihan ke menjadi node pertama dalam decision tree karena memiliki information gain yang tinggi. Baris total kolom Entopy pada Gamnar 2 dapat dicari dengan menggunakan rumus berikut ini :

Entropy $($ Total $)=\sum_{i=1}^{n}-p i \log 2 p i$

$$
\begin{aligned}
& \left.\left.=2 / 5^{*} \log 2(2 / 5)\right)-3 / 5^{*} \log 2(3 / 5)\right) \\
& =-(0,4) *(-1,3219281)-(0.6) *(-0,7369666)) \\
& =0,52871124+0,44217996 \\
& =0,97095084
\end{aligned}
$$

Gain $($ total tenaga kerja $)=$

$$
\begin{aligned}
& =\text { entropy (total) } \\
& \quad \sum_{i=1}^{n}\left|\frac{\text { tenaga kerja }}{\text { total }}\right| \\
= & 0,97095084-(0,6) * \frac{45}{0,97095084} \\
= & 0,97095084-\frac{27}{0,97095084} \\
= & 0,97095084-27,807793 \\
= & -26,83684
\end{aligned}
$$

Gain $($ total area $($ ha $))=$

$$
\begin{aligned}
- & \sum_{i=1}^{n} * \mid \frac{\mid \text { today } \mid}{\mid \text { total } \mid} \\
= & 0,97095084-(3 / 5) * \quad 5.12 \\
& 0,97095084 \\
= & 0,97095084-(0,6) * 5,27319 \\
= & 0,97095084-31,163914 \\
= & 2,19297
\end{aligned}
$$

Gain $($ total mtd $)=$

$$
\begin{aligned}
\text { Entopy }(\text { total })-\sum_{i=1}^{n} \mid \frac{\mid \text { mtd } \mid}{\mid \text { total } \mid} \\
=0,97095084-(0.6) * 0 \\
=0,97095084-0 \\
=0,97095084
\end{aligned}
$$

Gain $($ total ytd $)=$

$$
\begin{aligned}
& \text { Entopy (total) }-\sum_{i=1}^{n} \mid \frac{|y t d|}{\mid \text { total } \mid} \\
& =0,97095084-(0,6) * 1400 \\
& =0,97095084-\frac{840}{0,97095084} \\
& =0,97095084-865,131,1339 \\
& =-864,16039
\end{aligned}
$$


Kesimpulan :

1. Atribut dengan Gain tertinggi pada NODE 1 produksi yaitu 5

2. Atribut produksi menjadi NODE 1 (akar)

3. Nilai atribut produksi yaitu 2 bulan keterangan meningkat dan menurun. Sedangkan nilai atribut produksi yaitu 2 bulan.

Pada tahap ini, peneliti melakukan hasil klasifikasi dari metode decision tree yang diolah dengan menggunakan aplikasi data mining yaitu aplikasi WEKA.

\subsection{Data Mining Menggunakan Weka}

Setelah penjelasan proses penerapan data mining denga teknik classify secara teoritis pada penjelasan diatas, maka selanjutnya akan dijelaskan proses data mining secara aplikatif dimana proses data mining yang akan dilakukan menggunakan perangkat lunak data mining yaitu Weka V3.8.0. Seperti yang telah dijelaskan pada bab sebelumnya weka dalah sebuah aplikasi open source, weka memiliki 4 tools menu yang bisa digunakan, antara lain Explorer, experimenter, Knowledgeflow, dan Simple CLI, untuk penelitian ini penulis menggunakan menu Explorer.

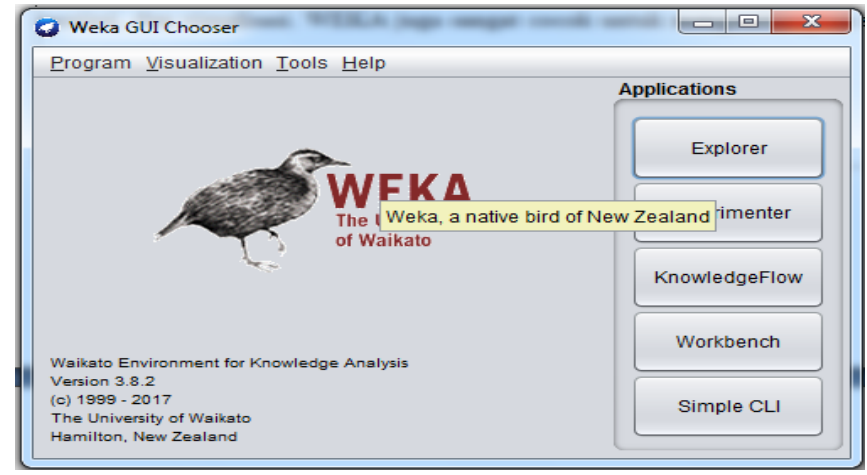

Gambar 3. Tampilan awal aplikasi weka

Fungsi 4 tools menu diatas antara lain :

1. Explorer, digunakan untuk menggalih lebih jauh data dengan aplikasi weka.

2. Experimenter, berguna untuk melakukan percobaan dengan oengujian statistic skema belajar.

3. Knowledge Flow, digunakan untuk pengetahuan pendukung.

4. Simple CLI, antar muka dengan tampilan command line yang memungkinkan secara langsung mengeksekusi perintah weka untuk system operasi yang tidak menyediakan secara langsung. 
Dalam rangkaian proses data mining menggunakan weka ini data yang digunakan adlaha data yang telah ditransformasi kedalam format microsoft Excel 2007 (csv) baru selanjutnya proses data mining dilakukan dengan menggunakan menu Explorer Open File pada Weka, lalu pilih data yang telah disimpan dalam format csv.

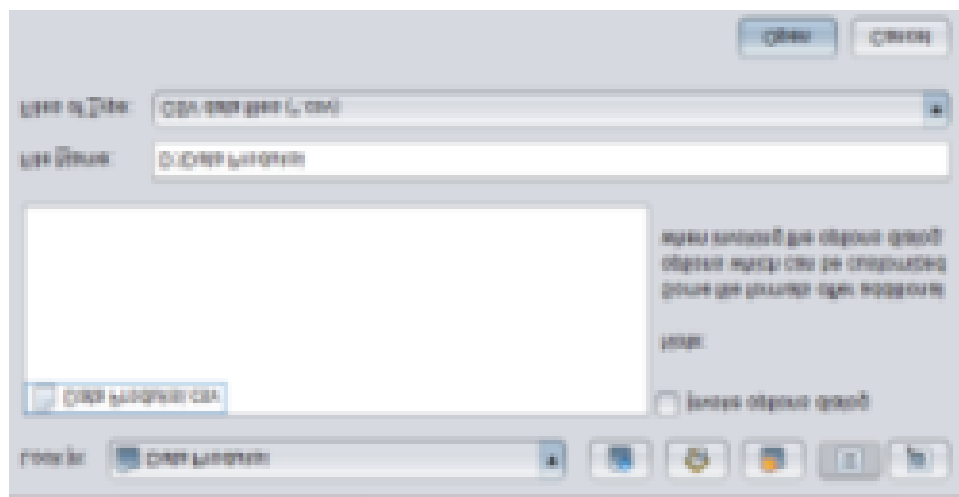

Gambar 4. Menu Explorer pada Weka

Dari pengetahuan yang telah dilakukan pada gambar 4. di atas pengaturan awal tersebut memiliki tujuan supaya data yang akan diproses pada aplikasi weka telah memenuhi standar weka yang dimana data akan diproses format file yang telah diubah menjadi csv (comma delimited).

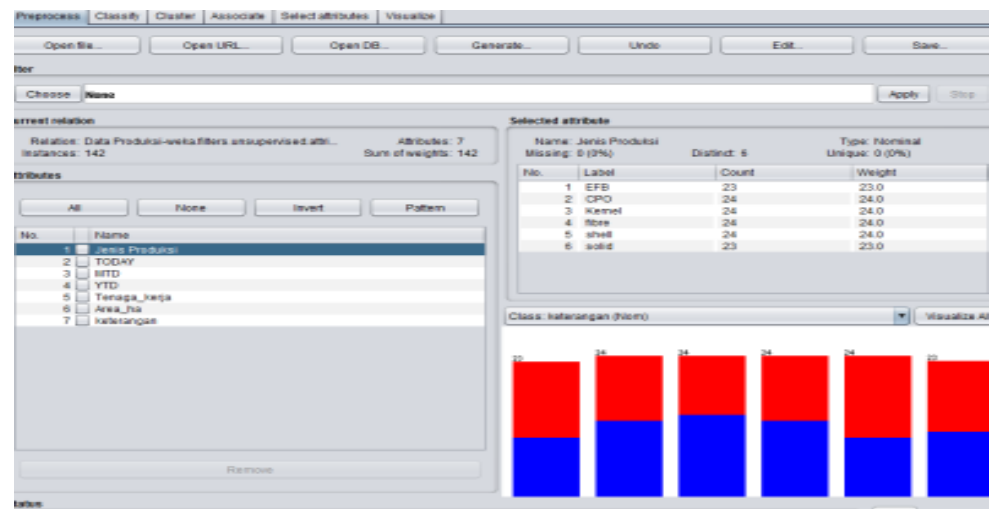

Gambar 5. Tampilan Awal Proses

Dihasilakan beberapa atribute yang tampil dalam menu tersebut, yaitu Jenis produksi, Today, Mtd, Ytd, Tenaga Kerja, Area Ha, dan keterangan. 
Didalam menu preprocess ada yang namanya filter klik choose setelah dipilih klik filter dipilih lagi unsur pervised dan atribut pilih NominalToBinary maka akan muncul tampilan seperti gambar dibawah ini.

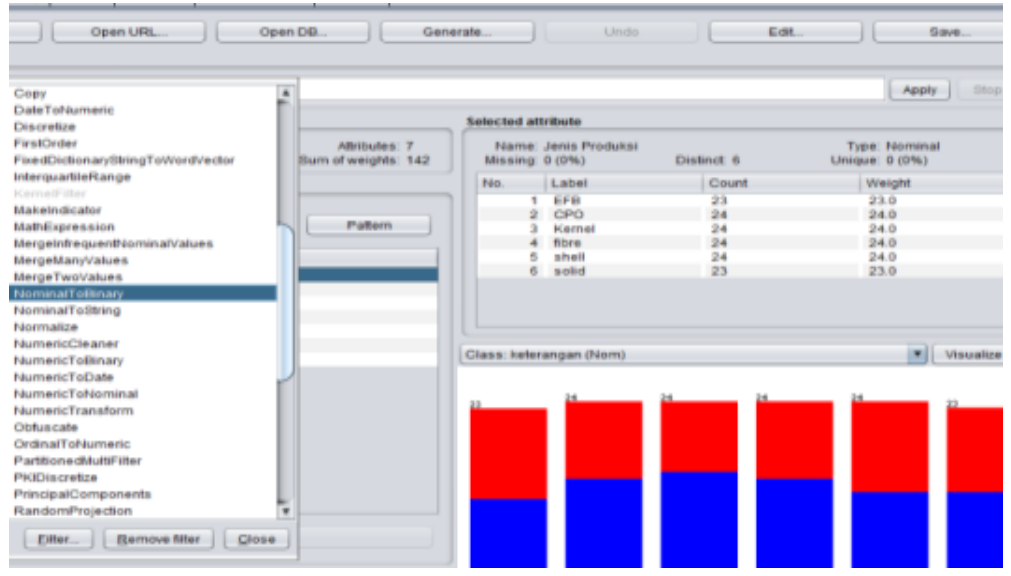

Gambar 6 Tampilan Pemilihan Filter

Setelah melakukan pemilihna filter untuk melakukan klasifikasi, dan sudah menemukan metode yang paling cocok, tentu kita akan menggunakan hasilnya untuk memprediksi hasil klasifikasi dari sekumpul data. Di sini filter yang dipilih adalah NominalToBinary, prosesnya dapat dilihat pada gambar 7 .

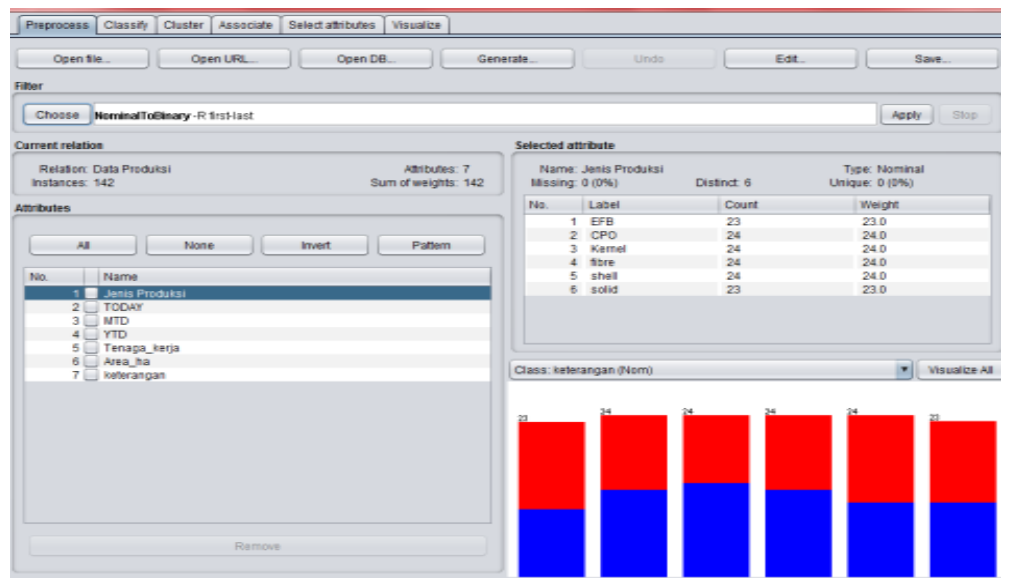

Gambar 7 Tampilan Pemilihan Filter

Untuk menerapkan metode classify dan algoritma J48 merupakan implementasi dari C4.5 pada data yang telah relevan maka dapat dilakukan dengan menggunakan menu Classify . 


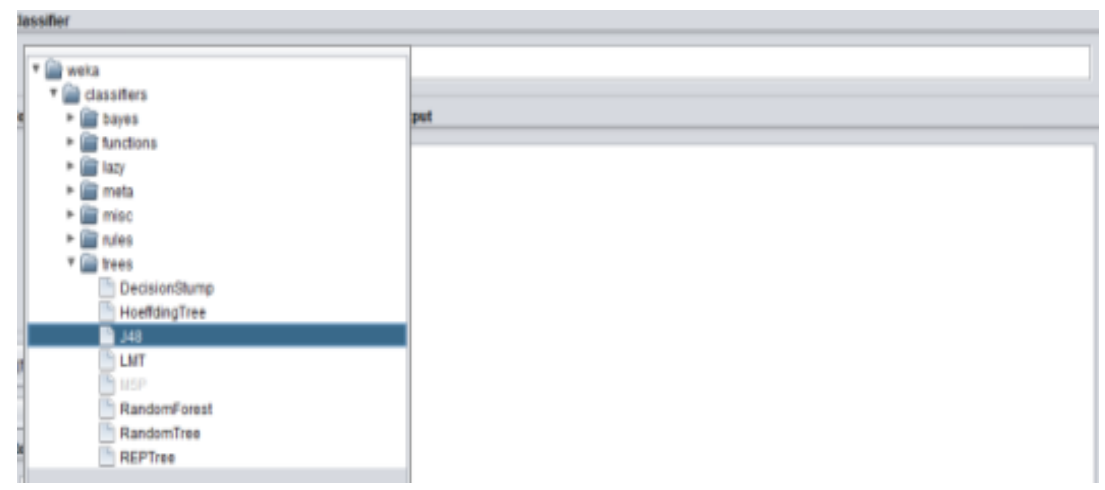

Gambar 8 Menu pemilihan algoritma

Pada gambar 8 algoritma yang digunakan adalah algoritma J48 yang merupakan implementasi algoritma $\mathrm{C} 4.5$ salah satu algoritma penganalisisan data untuk data atau metode data mining yang melakukan proses pemodelan tanpa supersive (Unspersived) dan merupakan salah satu metode yang melakukan pengelompokkan data sebagai system partisi. Setelah melakukan langkah penentuan teknik serta algoritma yang dibutuhkan, maka kemudian setelah itu akan tampil beberapa pilihan beberapa sub menu use training set, supplied test set, cross-validation, percentage split. Dan dalam penelitian kali ini akan menggunakan salah satu option set saja yaitu use training set karena pada dasarnya semua option tersebut akan menghasilkan hasil yang sama maka digunakan satu saja.

\section{KESIMPULAN}

Bersadarkan dari penelitian yang sudah dilakukan dan telah diuraikan dalam penerapan data mining pada Produksi kelapa sawit Di Sungai Lilin Kabupaten Musi Banyuasin, maka penulis dapat menarik beberapa kesimpulan sebagai berikut:

1. Penelitian ini menghasilkan penerapan data mining untuk menganalisa stok produksi yang akan diprediksi menggunakan decision tree Produksi kelapa sawit Di Sungai Lilin Kabupaten Musi Banyuasin.

2. Variabel produksi adalah variabel yang menentukan tingkat pola meningkat dan menurun dalam sebuah data produksi.

3. Rata-rata klasifikasi decision tree dalam melakukan klasifikasi data mencapai akurasi diatas 90\%. Hal ini menunjukkan bahwa decision tree tersebut memiliki performa yang handal dalam klasifikasi.

4. Decision tree tetap dianggp sebagai Decision tree yang sangat membantu dalam melakukan klasifikasi data produksi karena 
karaktersitik data yang diklasifikasi dapat diperoleh dengan jelas baek dalam bentuk struktur pohonn keputusan, sehingga memnudahkan pengguna dalam melakukan penggalian informasi terhadap data yang bersangkutan.

\section{DAFTAR PUSTAKA}

Aradea,2011."Penerapan decision tree penentuan pola data penerimaan mahasiswa baru". Semarang:Jurnal Ilmu computer unveersitas diponegoro.

Andie,S.Kom., M.Kom, 2016.”Penerapan decision tree untuk menganalisis kemungkinan pengunduran diri calon mahasiswa baru":jurnal Ilmiah Fakultas Teknik "Technologia".

Ari Muzaki,2016." Model Data Mining sebagai Prediksi Penyakit Hipertensi

Kehamilan dengan Teknik Decision Tree".jurnal Jurusan Informatika,

F. ILKOM, Universitas Bina Darma Palembang.

Defiyanti, S., Pardede \& Crispina, D. 2014. "Perbandingan Kinerja Algoritma

ID3 dan C4.5 dalam Klasifikasi”.s.1.:Jurnal Jurusan Sistem Informasi Universitas Gunadarma.

Dr. Suyanto. 2017." Data Mining untuk klasifikasi dan klasterisasi data". Bandung: Informatika Bandung'.

David Hartanto Kamagi, Seng Hansun,2014.” Implementasi Data Mining dengan Algoritma C4.5 untuk Memprediksi Tingkat Kelulusan Mahasiswa". Tangerang:Jurnal Program Studi Teknik Informatika.

Fitroh,2016."penentuan penerimaan siswa baru menggunakan decision tree".semarang:jurnal illmu computer

Han and kamber,2006," Data Mining untuk klasifikasi dan klasterisasi data". Bandung: Informatika Bandung' computer unveersitas diponegoro.

Nazir,m.(2005 : 54 ). Metode penelitian Jakarta:Ghalia Indonesia.

Prasestyo, Eko,(2014).Data mining mengolahan data menjadi informasi menggunakan matlab. Yogyakarta:CV.Andi Offset.

Sijabat, Alimancon.(2015),"penerapan data mining untuk pengolahan data siswa dengan menggunakan metode decision tree",(studi kasus:yayasan perguruan Kristen andreas) Medan:STMK Budi Darma Medan.

Suyanto. 2017." Data Mining untuk klasifikasi dan klasterisasi data". Bandung: Informatika Bandung' 
Turban, Efraim, 2011. "Decision Support Systems and Intellegents System, 9th Edition, Pearson/Prentice Hall”. Di akses pada tanggal 16 Juli 2018.

http://www.kumpulancontohmakalah.com/2017/01/Definisi.Pohon.Ke putusan.Konsep.Dasar.dan.Prosedur.Pembentukan.html.

Yudho Giri Sucahyo,2003."Penerapan Data Mining, Artikel Populer IlmuKomputer. Pearson/Prentice Hall”. Di akses pada tanggal April 24 2003. http://www.kumpulancontohmakalah.com/2009/Definisi.ProsesTahap an dan Penerapan data mining.Pengertian data mining.Pembentuk.html.

Wawan, Laksito. (2011).”Pengelolaan Data “. Jakarta: Ghalia Indonesia. 